\title{
WRITING ADVERTISEMENT BY MEANS OF GENRE BASED APPROACH FOR TOURISM STUDENTS IN VOCATIONAL FACULTY
}

\author{
Nyoman Ardiana Listriyawati. \\ nyoman.ardiana@hangtuah.ac.id
}

\begin{abstract}
Genre Based Approach is known as an approcah which focuses on the function of the text. One skill that needs concerning in this study is writing because students sometimes found difficulties in writing due to lack of knowledge of the function of the text and the structure of the text. Through good knowledge of the text function piror writing, it will help the students write easily. This study attempts to investigate the application of Genre Based Approcah to tourism students for writing advertisement in English Class in Vocational Faculty of Airlangga University. It tries to find information concerning on the lecturer implementing the Genre Based Approach for third semester students, the modification done by the lecturer in the implementation of Genre Based Approach, and the students' work in response to the implementation of Genre Absed Approcah. Qualitative research is conducted in this study which involves the description, recording, and interpretation of condition that existed at that time. The data collection techniques were derived from observation and interview. Then, the analysis of the data was conducted through categorization, data display and drawing conclusion. The descriptions of the data analysis were presented textually. The results obtained from this study indicate several things. First, the lecturer has already implemented all stages in Genre Based Approcah with some modification that suitable with the students need. Second, the students' work has already met the purpose of advertisement that is to promote the tourism place and attract the reader to come and visit the place.
\end{abstract}

Keywords: Genre Based Approach, Writing Skill, Students’ work.

\begin{abstract}
Abstrak: Genre Based Approach dikenal sebagai pendekatan yang menitikberatkan pada fungsi teks. Salah satu keterampilan yang perlu diperhatikan dalam penelitian ini adalah menulis, karena mahasiswa terkadang mengalami kesulitan dalam menulis karena kurangnya pengetahuan tentang fungsi teks dan struktur teks. Dengan pengetahuan yang baik tentang fungsi teks tulisan sebelum menulis akan membantu mahasiswa dalam menulis dengan mudah. Penelitian ini mencoba untuk mengetahui penerapan Genre Based Approach pada mahasiswa pariwisata untuk menulis iklan di Kelas Bahasa Inggris di Fakultas Vokasi Universitas Airlangga. Penelitian ini bertujuan untuk mencari informasi mengenai dosen yang menerapkan Genre Based Approach untuk mahasiswa semester III, modifikasi yang dilakukan dosen dalam penerapan Genre Based Approach, dan hasil karya mahasiswa dalam menyikapi penerapan Genre Based Approach. Penelitian kualitatif dilakukan dalam penelitian ini yang melibatkan deskripsi, pencatatan, dan interpretasi terhadap kondisi yang ada pada saat itu. Teknik pengumpulan data diperoleh dari observasi dan wawancara. Kemudian, analisis data dilakukan melalui kategorisasi, penyajian data dan penarikan kesimpulan. Deskripsi analisis data disajikan secara tekstual. Hasil yang diperoleh dari penelitian ini menunjukkan beberapa hal. Pertama, dosen sudah menerapkan semua tahapan dalam Genre Based Approach dengan beberapa modifikasi yang sesuai dengan kebutuhan mahasiswa. Kedua, karya siswa sudah memenuhi tujuan periklanan yaitu mempromosikan tempat wisata dan menarik minat pembaca untuk datang dan berkunjung ke tempat tersebut.
\end{abstract}

Kata Kunci : Genre Based Approach, Keterampilan Menulis, Karya Siswa. 


\section{INTRODUCTION}

English for students in Indonesia is learned as a foreign language. It has not been becoming a language for daily communication as the first language is Bahasa Indonesia. In Indonesia, English is taught from kindergarten up to university level as nowadays English is used as international language for communication as stated by Baker and Westrup (2000:2) that in many countries, secondary and university courses are taught by using English. By teaching English in those levels, it is hoped that Indonesian students are able to use English as a language for communication.

To reach the above goal through teaching and learning process in college, there are two main points to be considered, the lecturer and the approach employed. Here, the lecturer should be able to determine a certain approach to be employed in classroom as the lecturer should know well the characteristics of the students in order to decide the most suitable approach to meet the learning goal. According to Larsen-Freeman (2000:ix) teachers who have known the approaches they use in classroom well, will become clearer about why and what they do. The lecturer needs to know well when learner needs more guidance and less ones. This will give the learner chance to explore the knowledge by themselves.

In order to give the chance to students to explore the knowledge, the lecturer in Vocational Faculty at Airlangga University has try to implement a certain approach as most students have difficulties in producing a text. Students sometimes cannot use the appropriate grammar rules, organize the text structure properly based on the topic, the purpose of writing, coherence and limited idea. Therefore, prior to produce a text, students must comprehend the way on how to compose a writing text and the lecturer must choose an appropriate approach to solve these problems. As in research conducted by Wirantaka, 2016 stated that the students did brainstorming, drafting, revising and editing to overcome the problem in organizing the text structure properly. While, the problems of coherence according to Suwandi, 2016 can be solved by using the cohesive devices like reference, conjunctions, ellipsis which are used to link one sentence to the other. According to Dirgeyasa, 2016 to get the purpose of writing, students must know the writing steps from dependent to independent.

Referring to the approaches that might be used in teaching and learning process, there are so many approaches which can be used in teaching and learning process. However, there must be the most appropriate ones to apply in the classroom depending on the learner need and learning goal. This is argued by Larsen-Freeman (2000:ix) that in deciding which approach will be used, the teacher must understand it based on the learners needs "the teacher will have the understanding to do so, if they are able to and want to". By using the suitable approach, it will help to accommodate learners' needs so that the lecturer will handle the teaching and learning process in the classroom more easily.

One approach which is considered suitable for the college students in writing is a GenreBased Approach. This approach consists of four stages namely building knowledge of the field, modelling of the text, joint construction of the text and independent construction of the text. Hinai, 2018 stated that the absence of practicing learning and teaching academic writing partly discourage the acceptable mastering of these skills, hence the Genre-Based Approach to challenge that might be useful. Dirgeyasa, 2016 also stated that Genre-Based Approach will be one of the newest and practical, and effective one to teaching and learning writing since it provides reinforcement, new understanding, horizon, and insight toward genre and genre approach. Genrespecific composing instruction may be valuable since it presents a few cases to understudies who have as it were constrained presentation to true English composing. This approach can make the students to be aware of the different purpose of written text as it is focused on model of text and the key features with a clear idea of what a language features that should be expressed and how the content should be organized.

Students should understand that a communication is occurring in social context and it has a purpose. Furthermore, (Derewianka, 2003:135) states that the approach which emphasizes on the creation of meaning at the level of the whole text. This approach can provide students with. 
ample opportunities to become aware of the different purposes of written communication and the different ways information is organized in written text (Reppen, in Richards et all, 2002:304)

In this context, the genre approach was very beneficial as stated by Dirgeyasa, 2016 that genre as a product shows its distinctive features of writing either in terms of organization, physical design or layout and also communicative purpose and linguistics features used. Genre-Based Approach brings together formal and functional properties of a language in writing instruction, and it acknowledges that there are strong associations between them. Besides, the genre approach can energize understudies to take an interest with the world around them, to comprehend composing as instrument that they can utilize, and to realize how the author oversee substance to advance consistent organization.

The use of genre approach in teaching writing was already considered in the mid of 1980's as a framework for language instruction based on example of a particular genre as argued by (M.Byram, 2004:234) that the sort system underpins understudies composing with generalized, orderly directing rule almost how to deliver important messages. It has certain conventions or rules which are generally associated with a writer's purpose.

Teacher should introduce a variety of genres to get the students understand and practice different sets of skills in their lesson plan. Looking at this point Larsen-Freeman (2000:28) sated that teachers should think in terms of activities rather than methodological choices when they plan their lessons as in this approach is implemented in building knowledge of the field stage. Teacher should be able to promote students in each stage which has its function in realizing a particular goal. These stages can lead the learner to produce a communicative text as learner would have good knowledge text organization and function.

A text, is effectively communicate to the reader if the meaning is easily to be understood by the participant; particularly in writing that need of language skill and most of students may find writing as a difficult subject. Richards and Renandya (2002:303) claimed that there was no doubt that writing was one of the language skills that considered difficult for L2 learners to be mastered. The difficulties were not only generating and organizing the ideas but also translating these ideas into readable text. Therefore, the students must master the vocabulary and the structure of the text in order to produce a text that is acceptable in social context.

In producing a text, the teacher should be aware of the material used in teaching as it can promote students to explore their knowledge. Teacher may use a model or give sample text to illustrate a particular feature of the text under studied as stated by Hyland (2003b:87), representative samples of the target discourse can be analyzed, compared, and manipulated in order to make students aware to the fact that writing differs across genres and that they may needed to draw on the particular structures and language features under studied to achieve their writing goals. Grammatical forms were also important to help the meaning that wants to be conveyed to the reader can be accepted well. The teacher gave enough information and guidance to stimulate students for producing a text effectively although it was only a short one.

There were some previous studies related to GBA and its implementation. The first study was conducted by Wardhani (2012) in Surabaya. She focused on the teacher role in implementing Genre based approach in teaching narrative writing to First Grade students of a senior high school. She described the way of teaching in each stage in Genre Based Approach. The result indicated that the teacher not provided optimal guidance to the students in all stages. This study showed that teacher did not know well the procedure in implementing GBA.

The second study was conducted by Cahyaningsih (2013) in Surabaya. In her study, she focused on the process of teaching and learning of descriptive text using genre based approach and students writing ability when they are taught using genre based approach. This study also showed that the teacher did not know the procedure of GBA.

Those finding from the previous study led this research to be conducted, in which to seek for the evidence whether or not the implementation of GBA in Vocanioanl faculty of Airlangga University meet the appropriate GBA procedure that assumed the lecturer knows well the procedure of GBA and implements them appropriately and how was the students' work in producing advertisement after treatment using GBA. 
Based on the background and research problem, the research questions are formulated into:

1. How is the implementation of Genre Based Approach to students of tourism faculty in Airlangga Univeristy for writing advertisements and why the lecturer modifying the GBA procedure?

2. How is the students' work in response to the implementation of Genre Based Approach in producing advertisement?

\section{METHODS}

This study is planned to investigate the implementation of Genre Based Approach to tourism students in English class of Vocational Faculty at Universitas Airlangga Surabaya. Based on two research questions, a descriptive qualitative design, to describe clearly the result of this study, was employed in this research in order to obtain the related information of the implementation of genre-based approach for college students. As a qualitative research, the researcher would obtain an in-depth look at a particular individual, say, or a specific situation. As stated by Ary,et al (2010:22) a descriptive qualitative research emphases on understanding social phenomena from the viewpoint of the human applicants in normal settings.

In this study, the observation done in the class about the implementation of Genre- Based Approach and the students work after the implementation of the approach. The observation done in order to find out whether the lecturer had implemented the approach correctly and the students work are as expected. The words and sentences were used to represent the data to be analyzed and get the conclusion in this study that presented as description. The data described in some details, the setting or context occurred. Lastly, the observation was done in the class during the process of teaching and learning writing and the report produced was an interpretation of the participant's experiences.

In this research, the real phenomenon of the lecture's activity and sample text given to the students was being observed, as argued by Creswell (2012:16) a central phenomenon is the key concept, thought, or handle examined in subjective inquire about. Thus, the research problem requires both an exploration and an understanding (because of its complexity) of the process of teaching and learning.

Every activity done by the teacher related to the application of the approach will be described in detail. The condition and situation that occur in the classroom during the application of the approach in order to support the collection of the research data was also being observed.

The subjects of this study were the lecturer and tourism students of Vocational Faculty of Airlangga University.The activities done by the lecturer in implementing GBA whether or not meets the appropriate procedure and the students' work in response to the implementation of all stages in GBA to produce advertisement was being observed.

In this research, to collect the data were employed by conducting observation and interview. According to Miles, Huberman, and Saldana (2014) the data in qualitative research in the form of words that was language in the form of extended text. The qualitative researcher was beginning to focus on the study's issues, the cases to be studied, the data to be collected, and how these data will be managed and analyzed.

The data of the study consists of verbal and non verbal of lecturer and students through observed participants in their work that would become a qualitative database. Verbal behavior was involving the lecturer's instruction, questions and explanation also student's comment. While the non- verbal behavior was include lecture's and student's gestures, body movement, action and activities. With each form of data, the information was gathered as much as possible to collect detailed accounts for a final research report.

In this study the observation was recorded in all of its richness. Hence, all the information was recorded in order not to ignore anything that might provide insight to a situation. In other words the participants' thought was captured as accurately as possible. 
In a descriptive research the data was analyzed inductively, in which all findings during data collection would be useful to develop the research report. According to Miles et al. (2014) qualitative data analysis that are useful during the early stages of a study, often while data collection is going on. They help organize data for later and deeper analysis. The data would be used to describe a comprehensive report on practicing the teaching procedures.

Before analyzing the data, the researcher would organize the data first because it was critical in qualitative research since the large amount of information gathered during a study. Afterwards, the data would be transcribed as the data gathered was in the form of words and it need to be transcribed to be text data. And the next step is analyzing the data.

The research was conducted by observing the class activity and the process of teaching and learning was not interfered at all. By doing observation to the activities during the teaching and learning process, some notes was taken to add the important information which was needed. The classroom's condition was also being observed in order to figure out the interaction among the students and the interaction with the lecturer in regards to students' response during the class activities and problems which might occur in writing activity. This was done from the beginning until the end of the class.

Another technique to gain the data in this research was conducting an interview. The interview to the lecturer was done after the class finish in the vocational faculty Airlangga University. This was done to completed data from observation activity in order to get the comprehensive data. As stated by Given (2008:422) interviews are suitable for data collection in a variety of research methodologies, including grounded theory and ethnography, and are often used as a stand-alone strategy of information collection without dependence on an fundamental philosophical approach. Through interview the subjects were encouraged and prompted to talk in depth about the topic under investigation without the researcher's use of predetermined, focused, short answer questions. Further, Creswell (2012:218) said that in qualitative research, you ask open-ended questions so that the participants can best voice their experiences unconstrained by any perspectives of the researcher or past research finding.

For analyzing the students' work the researcher was using rubric as shown on below table:

Table I Scoring Rubric for written advertisement

\begin{tabular}{|c|c|c|c|c|c|c|}
\hline \multirow{2}{*}{ Students Group } & \multirow{2}{*}{ Criteria } & \multicolumn{5}{|c|}{ Score } \\
\hline & & 1 & 2 & 3 & 4 & 5 \\
\hline Group 1 until Group 7 & $\begin{array}{l}\text { Target market and persuasive } \\
\text { Techique: } \\
\text { (a) the target market is clearly } \\
\text { identified } \\
\text { (b) the persuasive technique is } \\
\text { appropriate for target market } \\
\text { Image and Slogan: } \\
\text { (a) the image would catch a } \\
\text { reader's attention } \\
\text { (b) The image appeals to the target } \\
\text { market } \\
\text { (c)the image is colorful } \\
\text { (d) the slogan is catchy and } \\
\text { creative } \\
\text { Text : } \\
\text { (a) Describe the location } \\
\text { (b) suggest reason to visit the } \\
\text { place } \\
\text { (c ) Explain how to go to the } \\
\text { place }\end{array}$ & & & & & \\
\hline
\end{tabular}




\begin{tabular}{lccccccc}
\hline \multirow{2}{*}{ Students Group } & Criteria & \multicolumn{5}{c}{ Score } \\
& & 1 & 2 & 3 & 4 & 5 \\
\cline { 2 - 7 }
\end{tabular}

Spelling, Grammar, Mechanics :

(a) correct spelling

(b) correct sentence structure

Note:

$5=$ Excellent (beyond the goal)

$4=$ Good (met the goal)

$3=$ Fair (has a few errors/some evidences of goal intention)

$2=$ Poor (has many errors/very little evidence of goal)

$1=$ No evidence of goal; very little thought or effort

\section{RESULTS AND DISCUSSION}

This study was conducted to investigate the implementation of Genre Based Approach for teaching writing to tourism students in English class of Vocational Faculty at Universitas Airlangga Surabaya which focused on third semester students.

From the observation and interview, the results indicated several things that could answer the questions related the implementation of Genre Based Approach and the students' work in response to implementation of Genre Based Approach.

The observation in class found that the lecturer had implementing all stages in Genre Based Approach to tourism students to produce written advertisement. The stages are building knowledge of the field, modelling of the text, joint construction of the text and independent construction of the text. Here, the lecturer was giving initial explicit knowledge and guided practice, moves to sharing responsibility for developing texts, and gradually withdraws support until the learner can work alone. The lecturer tried to create an attractive situation with some activities in building knowledge of the field and modeling of the text stage. Those activities can encourage students to express their opinion and knowledge of advertisement prior they produce an advertisement.

The activities in the building knowledge of the text or setting the context by gave sample on how to do verbal promotion of tourism object and let the students do the same in order they will experience to do verbal promotion. This activity was done for improving students speaking skill for communication as the basic need for the students of tourism is good communication in English either verbal or written. This was informed by the lecturer that improving communication skill is crucial for the tourism students.

The students need to identify key functions such as describing, explaining, analyzing, recording and evaluating and then decide relevant genres to include in each theme that would help to develop these functions. The choice of genre is strongminded by the nature of the subject or theme of the unit of work. Here, the lecturer knew on how to improve the students speaking skill by giving the activity of doing the verbal promotion.

Once the students performed to do verbal promotion, the lecturer was explaining about the nature of advertisement. It was related with the function and the key feature of advertisement. By instructing the students to do verbal promotion, the lecturer was giving the opportunity to the students to mention what they know about advertisement prior gave the explanation. This was done in order to stimulate the students own knowledge from their experience.

The activity of giving sample of verbal promotion and students performed to do verbal promotion was giving the opportunity to the students to explore the knowledge of the text function. This stage is important as the lecturer and students cooperatively build up a shared 
knowledge of the field as to encourage students to speak and express their ideas and to enable the lecturer to learn from them.

The communication between the lecturer and the students also run well as the questions from the lecturer was answered by the students actively. By giving the positive feedback to the students it will make the teaching and learning process become successfully.

In the modeling of the text, the lecturer gave sample video of advertisement. The video was about gadget advertisement. The activity was done for giving illustration to students of good advertisement and the function of promotion. Students were asked by the lecturer what makes advertisement is good and how to attract the customer.

In this stage the lecturer had given the model text in the form of video advertisement that could stimulate the students to practice their listening skill. The lecturer interventionist role was exposed as he ensuring that the students were able to understand the typical rhetorical patterns they need to express their meanings. The lecturer hoped that students will be familiar with the purpose, generic structure, and language features of the text will be produced. Both the lecturer and the students should work together to investigate the structural pattern and language features in order to comprehend the text, improving vocabulary, familiar with the components.

After watching the sample video of advertisement and discussed it, the next stage was joint construction of the text. In this stage the students were sitting in group to make a draft of guide book. This activity was done to give a chance for the students to share the information among them about the tourism places that they had visited. According to the lecturer by grouping the students it will spread the students from lower up to higher level in each group for help each other in order to improving their communication skill. This was in line with Derewianka (2003:148), that the students should be actively participate by providing the "subject matter" for the text.

In this stage the role of the lecturer is to demonstrate how that subject matter can be organized into a coherent text. The students will discuss and share information regarding the topic, as Hyland (2007:158) stated that the concepts of supporting learning is to assist learners through two notions of learning:

a. Shared consciousness - the idea that learners working togetherlearn more effectively than individuals working separately.

b. Borrowed consciousness - the idea that learners working with knowledgeable others develop greater understanding of tasks and ideas.

In this stage, the students were already worked together with their friends in group to produce a draft for advertisement. They share their knowledge each other from the data they had and video that they had watched before. They were giving input each other and looking for additional information from the brochure they had in making a draft.

In joint construction of the text the lecturer should guide the students to make a text. While in the research finding the lecturer let the students work among them in the group to make a draft first. Derewianka (2003:148) argued that the role of the teacher is to demonstrate how that subject matter can be organized into a coherent text. Based on the research finding the students choose the place the location to be advertised by themselves and they did not get input from lecturer to organize the text as the lecturer convinced that the students were already understand to make a draft as they already saw the sample video previously. At last of the meeting, the students were able to made a draft with some revised needed from their own effort.

Independent construction of the context was the last stage in composing process. The writer found that the students were asked by the lecturer to develop their revised draft into a complete text of written advertisement. The lecturer let the students working by themselves to make a text based on their revised draft. He gave the assistance to students who found difficulties to develop a text. He always reminded the students to pay attention on the grammar, cohesion and coherence of each sentences in order to make a good paragraph. This was in line with (Hyland, 2007:151) which said that teachers of writing clearly need to be teachers of language, as it is an ability to exercise appropriate linguistic choices within the ways they treat and organize their theme for specific readers which makes students to grant their thoughts specialist. 
At the last stage, the students were instructed by the lecturer to write the full text of written advertisement independently. The lecturer only reminded the students to pay attention on the grammar, cohesion and coherence of each sentences in order to make a good paragraph. The lecturer only gave one chance to students to revise the draft one time, this was not in line with Emilia (2010:152) that said when the students wrote their drafts several times, having to revise and to edit their texts.

Generally, the lecturer had implementing all stages in genre based approach by giving some activities to students to produce written advertisement. Through genre based approach the students not only improve their writing skill, the students also could practice their speaking skill when they practice to do verbal promotion and practice the listening skill when they saw the sample video of advertisement. While in producing the full text of written advertisement, the students did not got much chance to revise more than one time and editing the draft as the limitation of the time of the subject lesson which is only 2 SKS. From above discussion, the writer was assuming that the approach might be implemented well if there were more time in this subject lesson.

It can be concluded that the lecturer had implement all the stages in genre based approach that can help the students to produce written advertisements. The modification done by the lecturer in terms of activity in each stage was supporting the students to produce written advertisement as the activities were able to stimulate the students' ability to communicate in English both verbal and oral. Thus, the implementation of this approach can be assumed successfully as the students were able to produce the written advertisement.

In this research there were two kinds of students' work, the draft prior they wrote full text of written advertisement and guide book as the final assignment for English subject lesson. Both draft and guide book, there are some inadequacy in generic structure. The students did not put good headline such as give words that can attract the customer to read it. The words could be an adjective such as beautiful, wonderful or fantastic. While the illustration of the place is already good enough as the students had put some photos of the tourism object that they advertised. The photos are relevance as most of them were the scenery around the objects.

While in language features, the students still need to be guided in grammar and vocabulary. They should be more familiar with the vocabulary in tourism and how to use those words in order to attract the reader. The students also need to learn about the use of adjectives and verbs. Among the most common verbs used for this purpose there are: "get", "have", "see", "come", "go", "look", "feel", "like". Most verbs in advertisement appear in simple present tense.

The students also have to learn more about the mechanics in writing advertisement. They have to know well how to put the correct comma and full stop in the sentence. This will influence the reader to be easier in understanding the message that will be delivered. The wrong placement of comma can change the meaning in the sentence. Through joint construction and independent construction stages, the students were guided step by step started to choose the tourism place, important information of the place, made a draft and write advertisement individually.

These activities were done as writing is a progressive activity and will able to make the students create a good writing as the students were already clear at the beginning for the idea prior to produce a text. And with guidance from the lecturer, the students will be able to organize the ideas as stated by Oshima and Hogue (2007:15) the next step is making a draft and the final step is composing a text and editing as well as making revision. Furthermore, Anthony Seow in Richards and Renandya (2002:315) the composing process as a private action may be broadly seen as comprising four primary stages: arranging, drafting, changing and altering.

From the students' work the finding indicate that the students were already able produce written advertisement. The students' works were already meets the purpose of advertisement that is to promote the tourism place and attract the reader to come and visit the place. Despite the students able to produce the written advertisement, they still need to be guided more in order their work to be more perfect.

Generally, their works can be classified to low, medium and high. Group 6 was categorize as low due to the target market and persuasive technique was poor, image and slogan was fair and 
text, spelling, grammar and mechanic was poor. Group 1 and 4 were categorize as medium due to the target market and persuasive technique was fair, image and slogan was fair and text, spelling, grammar and mechanic was fair. Group 2, 3, 5 and 7 were catgegorize as good due to the target market and persuasive technique was good, image and slogan was good and text, spelling, grammar and mechanic was good.

The students' work can be summarized in below table:

Table 2 The classification of students' work

\begin{tabular}{|c|c|c|}
\hline $\begin{array}{c}\text { Low } \\
\text { (Group 6) }\end{array}$ & $\begin{array}{c}\text { Medium } \\
\text { (Group } 1 \text { \& 4) }\end{array}$ & $\begin{array}{c}\text { High } \\
(\text { Group } 2,3,5 \& 7)\end{array}$ \\
\hline $\begin{array}{l}\text { The target market was not } \\
\text { clearly described and the } \\
\text { persuasive technique was not } \\
\text { appropriate to the target market. } \\
\text { The creativity in showing image } \\
\text { and slogan were fewer as well } \\
\text { as the description of the place } \\
\text { and suggestion to visit the place } \\
\text { were less. }\end{array}$ & $\begin{array}{l}\text { The target market was clearly } \\
\text { described and the persuasive } \\
\text { technique was appropriate to } \\
\text { the target market. The } \\
\text { creativity in showing image } \\
\text { and slogan were good as well } \\
\text { as the description of the place } \\
\text { and suggestion to visit the } \\
\text { place was good. }\end{array}$ & $\begin{array}{l}\text { The target market and } \\
\text { persuasive technique were } \\
\text { excellent as both were } \\
\text { noticeably to target market. The } \\
\text { creativity in showing image, } \\
\text { slogan and the description of } \\
\text { the place and suggestion to visit } \\
\text { the place were excellent. }\end{array}$ \\
\hline
\end{tabular}

From the above table there were 3 groups that classified as high, 2 groups as medium and 1 group was low indicating that most of students were able to produce written advertisement after the implementation of genre based approach. It can be concluded that the implementation of genre based approach is the to tourism students to produce written advertisement was successfully.

For the additional information to the richness of the data collection, the result of the interview showed that students were able to write and advertisement that meets the purpose of advertisement that is to promote the tourism place and attract the reader to come and visit the place. They have to share what they got not only for their own group but also another one.

On the other hand, there was a creative activity on how the lecturer implemented this approach. This activity was given to the students as to promote the students' ability to communicate in English both oral and written.

\section{CONCLUSIONS}

Based on the findings and discussion of the research, the conclusion of this research will be elaborated as follow:

The lecturer was had implement all the stages in genre based approach by using the activity that support the students to produce written advertisement. In the building knowledge of the text, the lecturer was instructing the students to perform verbal promotion. This activity was done in order to gave brainstorming section and stimulate students' ability in speaking.

Once the students done the verbal promotion, the next activity is watching the advertisement video about gadget. This activity was done in modeling of the text stage. After the students watching the video, the lecturer would give some questions related to the advertisement and the students will analyze the representative samples and to identify the key features as well as the variations which are possible. Through this activity the lecturer would like to ensure that that the students are already know the key feature of an advertisement that should be revealed in promotion such as the purpose and the language that can persuade the customer.

From above activities the lecturer was continuing to the next stage, it was joint construction of the text. In this stage the lecturer was divide the students into several groups and instructed the students to make a draft of their guide book. The draft was discussed in the class in order to find out the mistake and revise it. Once the draft was revised, the last stage is independent construction of the text. In this stage the lecturer instructed the students to write full text from the revised draft. The lecturer was still guiding the students as they might ask if there is problem occurred. The 
lecturer walked around the class to check whether any students found any difficulties. He was making sure that the students were able to write by them selves. Finally the students have to submit their work in the form of guide book as the final assignment.

The students' works are already meets the purpose of advertisement that is to promote the tourism place and attract the reader to come and visit the place. Despite the students able to produce the written advertisement, they still need to be guided more in order their work to be more perfect.

After the research done, there is some suggestion to the lecturer and the other researchers who want to take the similar research. The first suggestion is for the lecturer. In teaching learning process, the lecturers are expected to create an interesting class. The lecturer needs to explore more on the implementation and find innovation of activities in each activity in order to achieve the objective of the lesson. Additionally, the lecturer can make the design of the course prior teaching in class. This design will help the lecturer to support and guide the lecturer about what they are going to do in classroom.

Finally, the writer wants to suggest other researcher, especially those who are interested in the field of teaching writing to conduct some followed up researches concerning genre based approach. There are some explorations in every stage of this approach which can be developed into a research.

\section{REFERENCES}

Ary, Donald, Jacobs, Lucy Cheser, Sorensen, Chris, and Razavieh, Asghar. 2010. Introduction to Research in Education (8 ed.). Belmont, CA: Wadsworth, Cengage Learning.

Baker, Joanna, and Westrup, Heather. 2000. The English Language Teacher's Handbook. How to teach large classes with few resources London: Continuum.

Bazerman, Charles. 2008. Handbook Of Research On Writing. History, Society, School, Individual, Text. New York: Lawrence Erlbaum Associates. Lawrence Erlbaum Associates.

Bhatia, Vijay K. 2013. Analysing Genre Language Use in Professional Settings. Oxon: Routledge.

Brown, H.Douglas. 2000a. Teaching By Principles An Interactive Approach to Language Pedagogy (Second Ed.). San Francisco: Longman.

Brown, H.Douglas. 2000b. Teaching By Principles: An Intercative Approach to Language Pedagogy. San Francisco, California: Pearson ESL.

Byram, Michael. 2000. Routledge Encyclopedia of Language Teaching and Learning. London: Taylor \& Francis Routledge.

Cahyaningsih, Ropikoherna. (2013). Improving Student's Writing Skill Through Genre Based Approach At TenthGrader Of Senior High School Tuban. Universitas Negeri Surabaya.

Cameron, Schyrlet, and Myers, Suzanne. 2013. Comprehending Functional Text. Alabama: Mark Twain Media, Inc

Christie, Frances. 2005. Language Education in the Primary Years. Sydney: A UNSW Press Book.

Creswell, Jhon W. 2012. Educational Research. Planning, Conducting, and Evaluating Quantitative and Qualitative Research (Fourth ed.). Boston: Pearson Education, Inc.

Deng, Liming, Chen, Qiujin, and Zhang, Yanyan. 2014. Developing Chinese EFL Learners' Generic Competence. A Genre-based \& Process Genre Approach New York: Springer.

Derewianka, Beverly. 2003. Trends and Issues in Genre-Based Approaches RELC Journal Vol. 34 No. 2, 133-154.

Dirgeyasa, I Wy. 2016. " Genre-Based Approach: What and How To Teach and To Learn Writing". Canada: English Language Teaching; Vol. 9, No. 9.

Emilia, Emi. 2010. Teaching Writing: Developing Critical Learners 
Flemming, Laraine. 2011. Reading for Result (Eleventh ed.). Boston: Wadsworth Cengage Learning.

Flynn, Naomi, and Stainthrop, Rhona. 2006. The Learning and Teaching of Reading and Writing. West Sussex: Whurr Publishers Limited.

Given, Lisa M. 2008. The SAGE Encyclopedia of QUALITATIVE RESEARCH METHODS (Vol. 1\&2). California: SAGE Publications, Inc.

Hinai, Issa Al. 2018. “ A Genre-Based Approach to Developing Learning and Teaching Academic Writing Skills With Relation to The Omani Technical Context". Wilmington DE : SinoUS English Teaching, October 2018, Vol. 15, No. 10, 459-469

Hyland, Ken. 2003a. Genre-based pedagogies: A social response to process. Second Language Writing Vol. 12 No. 1, 17-29.

Hyland, Ken. 2007. Genre Pedagogy: Language, literacy and L2 writing instruction. Second Language Writing Vol. 16 No., 148-164.

Hyland, Ken. 2003b. Second Language Writing (J. C. Richards Ed.). Cambridge,UK: Cambridge University Press.

Kumaravadivelu, B. 2008. Understanding Language Teaching From Method to Postmethod. New Jersey: Taylor \& Francis e-Library.

Larsen-Freeman, Dianne. 2000. Techniques and Principles in Language Teaching (Second Ed.). Oxford: University Press.

M.Byram. 2004. Genre and genre-based teaching.The Routlegde Encyclopedia of Language Teaching and Learning. London: Routledge.

M.Manchon, Rosa. 2011. Learning-to-Write and Writing-to-Learn in an Additional Language. Amsterdam: John Benjamins Publishing Company.

Miles, Matthew B., Huberman, Michael, and Saldana, Johnny. 2014. Qualitative Data Analysis: A Methods Sourcebook (3 ed.). Thousand Oaks, CA: SAGE Publications, Inc.

Nation, I.S.P. 2008. Teaching ESL/EFL Reading and Writing New York: Routledge.

Oshima, Alice, and Hogue, Ann. 2007. Introduction to Academic Writing (Third ed.). New York: Pearsonn Education,Inc

Richards, Jack C, and Renandya, Willy A. 2002. Methodology in Language Teaching. Cambrige: Cambrige University Press.

Suwandi. 2016. "Coherence And Cohesion: An Analysis Of The Final Project Abstracts Of The Undergradute Students Of PGRI Semarang”. Semarang: Indonesian Journal of Applied Linguistics, Vol. 5 no. 2

Swales, Jhon M., and Feak, Christine B. 2000. Academic Writing for Graduate Students Essential Tasks and Skills A Course for Nonnative Speakers of English (English for Specific Purposes). Michigan: University of Michigan.

Wardhani, Aulia Kusuma. (2012). Genre Based Approach in The Teaching Of Writing To The First Grade Students Of A Senior High School. Universitas Negeri Surabaya.

Wirantaka, Andi. 2016. "Paragraph Writing of Academic Texts in an EFL Context". Yogyakarta: Journal of Foreign Language Teaching \& Learning Vol.1 No. 2. 